\title{
Cattle Farmers' Perception of Reproductive Failures and Their Effects on Cattle Production in the North West Region of Cameroon
}

\author{
NSONGKA Munji Victorine ${ }^{\star 1,2}$, \\ NCHINDA Valentine Petentsebe ${ }^{1}$, \\ WIRNKAR Venasius Lendzemo ${ }^{1}$, NDIP Lucy A. ${ }^{2}$, \\ KIMBI-MBUFONG Helen K., 3
}

\author{
${ }^{1}$ Institute of Agricultural Research for Development (IRAD Bambui), P.O. Box 80 Bamenda, \\ North West Region. \\ ${ }^{2}$ University of Buea, South West Region. \\ ${ }^{3}$ University of Bamenda, North West Region.
}

ARTICLE INFO

Article No.: 061918086

Type: Research

DOI: 10.15580/GJAS.2018.6.061918086

Submitted: 19/06/2018

Accepted: 23/06/2018

Published: 29/06/2018

${ }^{*}$ Corresponding Author

NSONGKA Munji Victorine

E-mail: vnsongka@yahoo.com

Phone: +237 690077234 ,

+237671803492

Keywords:

Bovine reproductive failures,

zoonoses, infertility, abortion,

embryonic death, brucellosis, RVF

\section{ABSTRACT}

Reproductive complications such as embryonic death, abortion and infertility are some of the problems which cattle breeders face in the North West Region of Cameroon although most of them may not realize the extent of economic loss that can occur through these reproductive failures in their herds. This study was aimed at assessing farmers' perception of reproductive failures and their effects on cattle production in the North West Region of Cameroon.

Primary data were collected using 216 structured questionnaires administered to household heads of cattle grazers, herdsmen and crop farmers in five Divisions (Boyo, Bui, Donga Mantung, Mezam and Momo) of the North West Region. Chi-square statistics were used to determine the differences in farmers' perceptions.

There were three categories of respondents; crop farmers $30(14.0 \%)$, cattle grazers $150(70.1 \%)$ which constituted the majority of respondents and herdsmen $34(15.9 \%)$. Embryonic death was the commonest reproductive failure observed $(25 \%)$ followed by abortion $(22.1 \%)$ and infertility $(7.4 \%)$. However, there was a significant difference in the level of perception of reproductive failures in cows by farmers in the five Divisions $\left(\chi^{2}=81.5\right.$, $d f=4 p \leq 0.001$ ). It was also observed that among the three categories of respondents [crop farmers (29), cattle grazers (145) and herdsmen (33)], the herdsmen $(90.9 \%) n=30$ ) were more aware of zoonotic transmission than the cattle grazers $(30.3 \%, n=44)$ and crop farmers (72.4\%, $\mathrm{n}=21), \chi^{2}=49.3, d f=2, p \leq 0.001$.

The level of perception of reproductive failures among cattle farmers was seen to be very low and certainly has a great impact on cattle production in the Region. More awareness campaigns on the risk of zoonotic disease transmission is needed to discourage the consumption of raw milk and the sale of dead animals in the communities. 


\section{INTRODUCTION}

Livestock production currently accounts for about $36 \%$ of the total agricultural production worldwide and almost one-third of the total production in developing countries (Alexandratos and Bruinsma, 2012). However, this does not satisfy the world demand for meat and other livestock products, which continues to increase due to demographic growth, urbanization, and economic development (Marcotty et al., 2009). Developing countries are expected to continue to increase their contribution in world production so that by 2050 they could account for 70 percent of world meat production and 61 percent of world milk production (Alexandratos and Bruinsma, 2012). This would give them greater access to global and regional meat markets and could bring millions of poor livestock keepers out of poverty if they effectively meet up with the rising demand (ILRI, 2012). In addition to the increasing demand, there is also more awareness of the importance of the dairy sector in developing countries as milk is an important source of protein, which could increase protein consumption in Africa and reduce child malnutrition (Ndambi et. al., 2008).

FAO estimates of 2006 showed that more than 850 million people globally were undernourished with the great majority found in developing countries (FAO Statistics Division 2006). It was later reported that in 2007, the number of undernourished people in the world increased by 75 million but this was mainly attributed to high food prices (FAO, 2008) giving a total of about 925 million people worldwide suffering from chronic hunger (FAO, 2011). However, there is a basic link between the challenge we face to ensure food security in the twenty first century and other global issues, like climate change, population growth and the sustainable management of the high demand for energy and water (Beddington, 2010).

Godfray et al., 2010 reported a marked increase in food production leading to a reduction of the proportion of hungry people worldwide but the world population also doubled with more than one in seven people still not having sufficient protein and energy from their diet. As the global population continues to grow, it has been estimated that it will likely stabilize at about 9 billion people by roughly the middle of this century, with increased wealth and higher purchasing power among the people (Godfray et. al., 2010). This will lead to more protein consumption and a greater demand for meat, dairy, and fish, resulting in increased pressure on the food supply system. In Sub Saharan Africa, the human population is expected to grow by $1.2 \%$ per year over the next 30 years (van Marle-Koster and Webb, 2014) and the proportion of people relying on livestock for some or their entire livelihood is also expected to be very high, ranging from $20 \%$ to over $90 \%$ (Haileselaisse et. al., 2011). Nonetheless, this population growth is prompting many governments to aim at a policy of food self-sufficiency and despite all the efforts put in place to increase agricultural production, malnutrition is still a challenge in many parts of the continent (Bayemi et. al., 2005). The
World Bank (2008) predicted a $50 \%$ rise in cereals demand compared to an $85 \%$ increase for meat between the year 2000 and 2030 .

Apart from being a valuable source of protein, livestock is also a source of income, fuel, draft power and manure in most developing countries. It contributes to food security and nutrition with about one billion poor people in the world depending on livestock production. For many small-scale farmers, livestock is also an important way of investment in times of need (Parente and van de Weerd, 2012). The expectation of any cattle producer is that his cows become pregnant, deliver healthy and productive calves in order to increase his income. When breeding cows fail to conceive, it directly affects the economic viability of the farm (Lamb et al., 2014).

Reproductive complications such as infertility and abortion are two main problems which the cattle breeders face although most of them may not realize the extent of economic loss that can occur through these reproductive failures in their herds (Sprott and Field 1998). Bovine reproductive diseases result in decreased production and delayed reproduction as well as increased cost of treatment and disease prevention (Bellows et al., 2002). These diseases often develop very gradually and may go unnoticed until the disease is well established in the herd. Infected animals especially bulls usually do not appear ill and some animals never even show symptoms of the disease at all and yet remain a major threat to the rest of the herd because they are carriers of the disease organisms (Sprott and Field, 1998).

These diseases are diverse and are caused by different pathogens; the most common include obligate venereal pathogens such as Tritrichomonas foetus and Campylobacter fetus subsp. venerealis which inhabit or affect only the reproductive tract while other pathogens like Rift Valley Fever virus and Brucella abortus which have the reproductive system as their main target organs also cause abortion after entering the body by the oral route or via exposed mucous membranes or aerosols in some instances (Irons, 2007). However, other common reproductive diseases in cattle like leptospirosis, Infectious Bovine Rhinotracheitis (IBR) and Bovine Virus Diarrhea (BVD) complexes, are also caused by other pathogens (Sprott and Field, 1998). Some of these diseases can be transmitted from animals to man and are commonly known as zoonoses.

When a cow or heifer does not become pregnant due to infertility, it is a huge economic loss to beef and dairy producers because there will be no economic return realized from the cow for at least one additional year except where the producers have multiple breeding seasons in a year (Lamb et al., 2014). Generally, infertility, regardless of the cause, is a major reason for culling most animals (Bellows et al., 2002). Some other reasons why breeding cows may not conceive include; anestrous/pre-puberty or poor management practices in the farm. In other cases, cows may also conceive but fail to calve because they lose their pregnancy at some stage of gestation because of a disease or a traumatic event. Either way, 
the economic impact of cows failing to calve is severe (Lamb et al., 2014).

In Cameroon, the livestock sector provides 125 billion CFA francs of the Gross Domestic Product (GDP) representing about 9 to $10 \%$ of the national GDP of the primary sector. It provides revenues to $30 \%$ of the rural population and is also a source of employment for many Cameroonians, like breeders, middlemen in cattle trade, processors, transporters and butchers. Livestock products, especially cattle beef makes up a significant part of the main diet of more than $60 \%$ of the Cameroonian population. Other products like milk, hides and skin are also highly consumed in some parts of the country, especially in the North West, South West and Northern Regions (Ngalim, 2015). However Cameroon still falls within those countries with the lowest per capita milk production and consumption (Ndambi et al., 2008).

The human population in Cameroon is expected to grow by more than $50 \%$ by the year 2030 , therefore the challenge for the livestock enterprise is to produce enough meat for the growing population and in order to meet up with the increased consumption rate, there is need to develop a viable livestock industry (Ngalim, 2015). Cattle production in the North West Region is mainly based on traditional production systems involving predominantly the rural population (Pingpoh et al., 2007). The cattle population in 2008 stood at 7 million heads (Ngalim, 2015) and more than $90 \%$ of the estimated population was found in four Regions, the Far North, the North, the Adamawa and the N.W. Region (Pingpoh et al., 2007; Ngalim, 2015). It constitutes mainly indigenous breeds like Gudali, Red and White Fulani; all zebu cattle, which by their genetic potential for milk production (1.8 litres of milk/cow/day), have been termed poor milkers when compared to exotic breeds like Holstein and Jersey, which under the same environmental conditions produce about $12 \mathrm{l} / \mathrm{cow} /$ day (Ndambi et al., 2008, Bayemi et al., 2010). The cattle farmers are exposed to various kinds of risk like weather conditions, diseases and pests and seasonal price variability. A period of four to five months of dry season (November to March) leads to lack of fodder and water for the animals (Pingpoh et al., 2007) thus causing the farmers to move their animals to lower valleys on transhumance where many other diseases and parasites are spread during this period, when animals from several herds graze together along fertile valleys or forest areas (Ndambi et al., 2008).

In the rural areas, most cattle grazers live in close proximity with their animals. The women and children always do the milking of the animals in the mornings under very poor hygienic conditions. The grazers and herdsmen on their part take care of the animals with very little or no hygienic and/or safety precautions. This potentially exposes them to zoonotic infections and can also create favorable conditions for the transmission of diseases from one animal to the other. Hence, knowledge on the presence of these infections and their mode of transmission is thus imperative. The impact of disease on cattle production in the North West Region is felt through mortalities and abortions or through morbidity, weight loss, reduced carcass weight and time and money involved in controlling or treating the effects of disease. The economic impact of losses due to mortality is often severe and easily quantifiable, but losses in production due to morbidity are difficult to estimate and this is where many farmers incur great losses. Most farmers have to cull their animals which are unproductive due to repeated abortions, return to oestrus, infertility or of poor body condition due to undefined diseases and sell at reduced cost leading to reduced income and herd size. This paper assesses the perception of reproductive failures among cattle grazers and their effects on cattle production in the North West Region of Cameroon in order to enhance the contribution of the livestock sector to sustainable food security and poverty reduction.

\section{MATERIALS AND METHOD}

An informed consent was obtained from each farmer before they were enrolled in the study. The informed consent explained the objectives of the study, the advantages of participating in the study and assurance of confidentiality. However, the farmers were free to choose to participate or not after they were duly enlightened on the nature and objectives of the study. Those who accepted to participate in the study thumbprint or signed on the consent in all the study locations presented in the next paragraph. The language used to administer the questionnaires was Pidgin English and in some cases there was need for an interpreter for some elderly men and women.

\section{Study Area}

This study was conducted in the North West Region (NWR) that lies between latitudes $5^{\circ} 45^{\prime \prime}$ and $9^{\circ} 9^{\prime \prime} \mathrm{N}$ longitudes $9{ }^{\circ} 13^{\prime \prime}$ and $11^{\circ} 13^{\prime \prime} \mathrm{E}$. It covers an area of about $17400 \mathrm{~km}^{2}$ and is bordered to the North and West by the Republic of Nigeria, to the South by the West and South West Regions and to the East by the Adamawa Region. Administratively, the North West Region is divided into seven Divisions namely: Boyo, Bui, Donga Mantung, Menchum, Mezam, Momo and Ngoketunjia (NIS, 2014). The topography of the Region varies greatly from depressions lower than $400 \mathrm{~m}$ to high mountains $3000 \mathrm{~m}$ above sea level and classified into three main zones: the lower altitude $(<900 \mathrm{~m})$; the mid altitude $(900-1500 \mathrm{~m})$ and the high altitude $(>1500 \mathrm{~m})$. The high mountainous areas are cold $\left(<15^{\circ} \mathrm{C}\right)$ such as Ndu and Nkambe whereas the low altitude zones are hot (average $27^{\circ} \mathrm{C}$ ) such as the Ndop plain and Ako Sub Division. There are two distinct seasons: rainy season (mid-March to midOctober) and dry season (mid-October to mid-March). Annual rainfall varies from $1,300 \mathrm{~mm}$ in the Ndop plain to over 3,000mm in Awing and Oku. The vegetation depends on the prevailing climate, altitude, soil conditions and human activities on the environment. The Region falls within the typical savannah zone covered predominantly with grass but around plains such as the Mbembe, Fura Awa and Widikum areas, the vegetation is predominantly forest. The climate, 
topography and vegetation make the North West Region an excellent Region for animal husbandry. The extensive, semi-intensive and intensive systems of animal husbandry practice at various scales in the Region involve large ruminants (cattle), small ruminants (goats and sheep), pigs, poultry and nonconventional livestock. Cattle production is practiced in Donga Mantung, Menchum, Bui, Boyo, Momo and
Mezam Division. This study was carried out in five of the six cattle rearing divisions of the NWR (Figure 1). There are several transhumance communities across all these divisions. For instance, the Ndop plain in Ngoketunjia Division serves as an important transhumance zone for the cattle population from neighboring Divisions and the West Region (Manu et al., 2014).

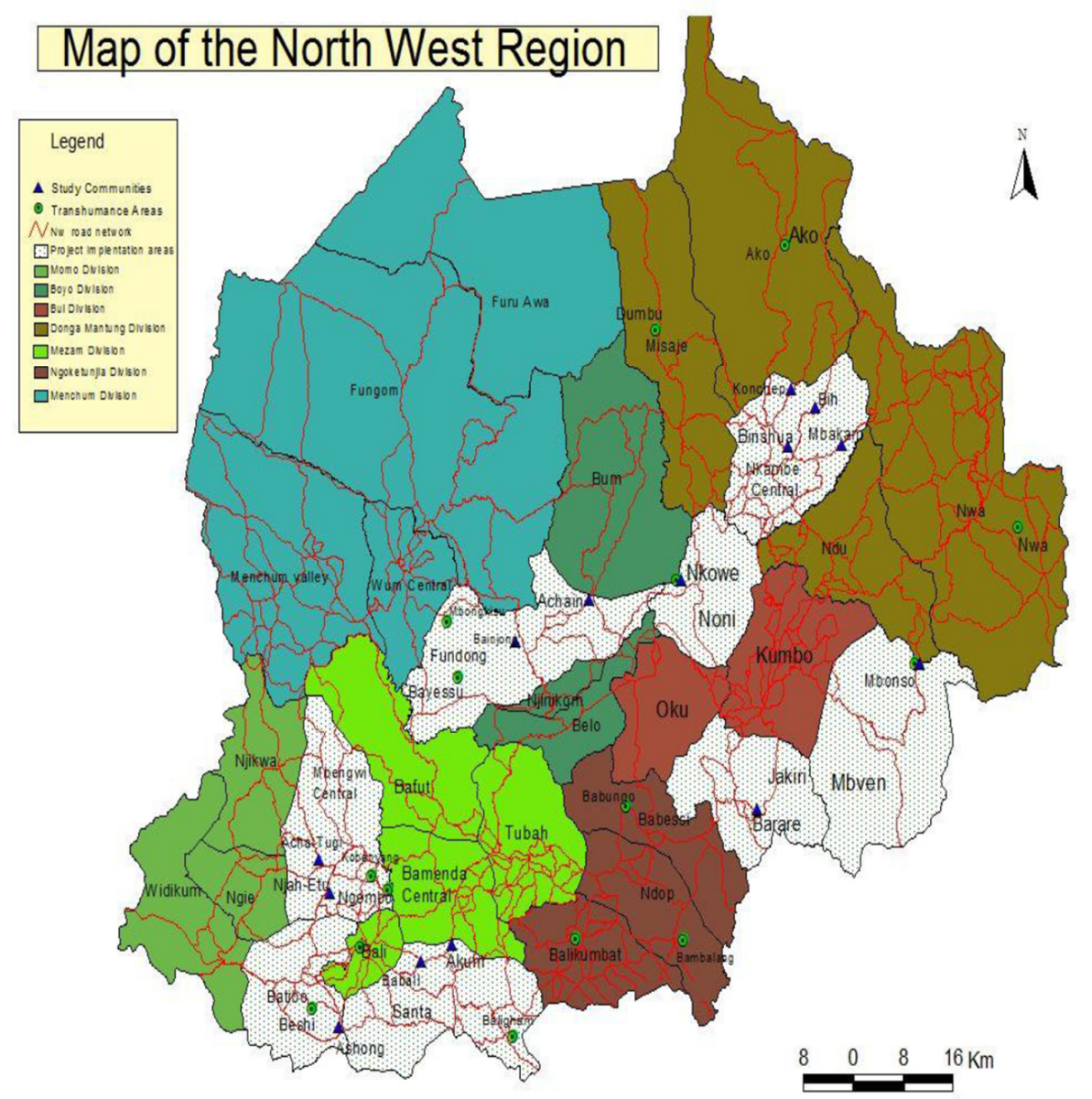

Fig. 1: Map of the study area in the North West Region (Nchinda et al., 2014)

\section{Sampling and Data collection}

Primary data for this study were collected with the aid of structured questionnaires administered to randomly selected crop farmers and grazer households (216) from November 2013 to February 2014 across five out of the seven divisions of the NWR of Cameroon. The choice of the study divisions and communities (Table 1) was guided by secondary data sourced from existing literature and reports of the Ministry of Livestock and Animal Industries (MINEPIA). The scale of cattle production and the existence of transhumance communities also motivated the choice of the study localities. Some cattle owners whose main activity was crop farming were also included in the study along with herdsmen.

The data collected for this study include farm characteristics and their management practices, breeding plan, grazing systems, infrastructure and also information on the farmer's perception of reproductive diseases and their effects as well as how they are treated.

Table 1: Total number of Respondents in the study

\begin{tabular}{|l|l|l|l|}
\hline Division & $\begin{array}{l}\text { No. of } \\
\text { Respondent } \\
\text { s }\end{array}$ & $\begin{array}{l}\text { Percentag } \\
\text { e (\%) }\end{array}$ & $\begin{array}{l}\text { No. of } \\
\text { communities }\end{array}$ \\
\hline Boyo & 27 & 12.50 & 2 \\
\hline Bui & 72 & 33.33 & 3 \\
\hline $\begin{array}{l}\text { Donga } \\
\text { Mantung }\end{array}$ & 37 & 17.13 & 5 \\
\hline Mezam & 40 & 18.52 & 2 \\
\hline Momo & 40 & 18.52 & 2 \\
\hline Total & $\mathbf{2 1 6}$ & $\mathbf{1 0 0}$ & $\mathbf{1 4}$ \\
\hline
\end{tabular}




\section{Data analysis}

The analysis was done using the Statistical Package for Social Sciences (SPSS), version 16.0. Descriptive statistics such as frequencies and percentages were used to present the results. Chi-Square analysis was also used to determine the statistical differences in the level of farmers' perception of reproductive diseases across the 5 Divisions in the North West Region.

\section{RESULTS AND DISCSSION}

\section{Socioeconomic characteristics of respondents}

Two hundred Fulani grazers were targeted for this study but at the end we had 216 respondents giving $108 \%$. Most of them were middle-aged men $83(38 \%)$ between the ages of 31 and 50 years. There were 26 $(12.1 \%)$ female respondents and $190(87.9 \%)$ male respondents although not all of them gave complete answers to all the questions on the questionnaires as shown in Table 2. However, 134 (63.2\%) of these respondents did not have any formal education while $44(20.8 \%)$ had primary school education. The difference in the level of education between men and women was highly significant $\left(\chi^{2}=14.22 ; P=0.001\right)$. There were also three categories of respondents; crop farmers $n=28(13.7 \%)$, cattle grazers $n=147(68.1 \%)$ which constituted the majority of respondents and herdsmen $n=30(14.6 \%)$.

\section{Reproductive failures}

The level of perception of reproductive failures was generally low among the respondents interviewed. Many of them associated embryonic death to return to estrus in the cows and this was the commonest reproductive failure observed $(25 \%)$ followed by abortion (22\%) and then a combination of embryonic death, abortion, infertility and reduced milk production (Table 3). Reduced milk production was only reported in Bui Division (7.1\%). This is because most of the grazers interviewed in this study, had mostly the indigenous breeds of cattle like White and Red Fulanis and the Gudalis which are generally poor milk producers giving between 1.5 to 3 litres maximum a day as reported by Bayemi et al. (2005), so they could not attribute low milk production to reproductive failures but in Bui Division due to the presence of exotic breeds in the Division the farmers could recognized reduced milk production as a problem when compared with the production from the exotic breeds. However, there was a significant difference $(P \leq 0.001)$ in the proportion of respondents who perceived reproductive failures in cows across the different Divisions where the study was carried out. It was also observed that there were some other common health challenges like Foot and Mouth Disease (FMD) commonly called "Mboro", bloody urine (Babesiosis), cough (TB) and diarrhea which were reported by $16 \%$ of the farmers interviewed although these infections were not the focus of this work as shown in Table 3. We also found that although their knowledge of reproductive failures was limited, they had indigenous knowledge and names for some of the diseases commonly occurring in the herds. Brucellosis for example, is commonly known amongst the Fulanis as 'Bakale' and they all admitted that it was a major cause of economic loss in their herds. They identified it through the various signs and symptoms observed in the cows like hygromas typically manifesting as swollen joints and abortion storms. Out of the 202 respondents who attempted to assess the period of the year when these reproductive failures were more frequent; only $2(1 \%)$ were not very certain of the period of occurrence. One hundred and thirty-seven $(67.8 \%)$ found the diseases more common all year round, $47(23.3 \%)$ reported that they occurred more in the dry season and $17(8.4 \%)$ observed the diseases more commonly in the rainy season as can be seen in Table 4. The degree of association between season and occurrence of reproductive failures was significant at $P<0.05$. Embryonic death, abortion, infertility and reduced milk production are consequences of some diseases of the reproductive system like brucellosis, RVF and trichomoniasis which cause reproductive failures in cattle. Brucellosis, RVF and fascioliasis are also listed among the neglected zoonotic infections in the developing. The presence of Brucella spp. in livestock is a serious threat to public health, since interaction with livestock and consumption of animal products are the main sources of infection in man (Marcotty et al., 2009). Recent studies carried out in the North West Region (Bayemi, et al., 2015 and Kong et al., 2016) show the level of prevalence of brucellosis in the Region to be $5.2 \%$ and $4.04 \%$ respectively.

\section{Grazing systems}

The predominant grazing system identified in the study area was free pasture grazing (Extensive). However, few cases of exclusively Intensive and Semi-intensive rearing systems were also identified. Consequently, most of those who participated in this study practice the extensive farming system $212(98.6 \%)$ as shown in Table 5. Most grazers do not have improved pastures planted for nourishment of the cattle but they all depend on the rangeland which is generally considered to be common property with no one taking the responsibility to maintain it. Consequently the rangeland is overgrazed and the animals have to move to the valleys in the dry season for survival. Pastures in the North West Region are mostly dominated with Sporobolus africanus, Pennisetum clandestinum, $P$. purpureum, Loudetia spp., Hyparrhenia spp, Urelytrum fasciculatun, Panicum phramitoides and Paspalum arbiculare, some improved species like Brachiaria spp, Trypsacum laxum, Stylosanthes spp. and some tree legumes (Bayemi et al., 2015)

\section{Transhumance activities}

Most or all the animals in this study go on transhumance during the dry season to the valleys where some pasture and water could be available for the animals (Table 6). A total of $81 \%(n=174)$ of the respondents take their animals on transhumance while only about $19 \%(n=40)$ remain in their original locality. 
There were areas of transhumance in all the Divisions although some of the respondents from Mezam, Momo and Bui had to go as far as Ngoketunjia Division which is a typical area for transhumance in the Region. The main transhumance areas identified were Mbonkisu for Boyo Division, Ngyen-Mbo in Momo Division, Mundum, Bafut in Mezam Division, Mbonso in Bui Division and Ako and Misaje in Donga Mantung Division.

Table 6: Proportion of grazers who go on transhumance in the Region

\begin{tabular}{|l|l|l|l|}
\hline \multirow{2}{*}{ Division } & \multicolumn{3}{|l|}{ Transhumance activities } \\
\cline { 2 - 4 } & Yes (\%) & No (\%) & Total (\%) \\
\hline Mezam & $38(21.8)$ & $2(5)$ & $40(18.8)$ \\
\hline Momo & $33(19.0)$ & $6(15)$ & $39(18.2)$ \\
\hline Boyo & $24(13.8)$ & $2(5)$ & $26(12.1)$ \\
\hline Bui & $49(28.2)$ & $23(57.5)$ & $72(33.6)$ \\
\hline $\begin{array}{l}\text { Donga } \\
\text { Mantung }\end{array}$ & $30(17.2)$ & $7(17.5)$ & $37(17.3)$ \\
\hline Total & $\mathbf{1 7 4 ( 1 0 0 \% )}$ & $\begin{array}{l}\mathbf{4 0}(\mathbf{1 0 0} \\
\%)\end{array}$ & $\mathbf{2 1 4 ( 1 0 0 \% )}$ \\
\hline \multicolumn{4}{|c|}{$\chi^{2}=\mathbf{1 5 . 6 , d f = 4 , p = 0 . 0 0 4}$} \\
\hline
\end{tabular}

\section{Disposal of dead animals}

Typically, the Fulanis do not have the habit of eating carcasses of dead animals so it was normal to see that most animals which died irrespective of the cause of the death, were not consumed as shown in Table 7, which results in huge economic loss to the farmer. It was observed that $6 \quad(3.9 \%)$ acknowledged consumption of dead animals, $96(62.3 \%)$ do not eat dead animals, but only $4(2.6 \%)$ bury the carcasses and $48(31.2 \%)$ sold the carcasses as meat to others. The results suggest that the proportion of respondents that eat meat from dead animals is low and significant $\left(\chi^{2}=62.7, \mathrm{P} \leq 0.001\right)$ across the divisions. Conversely, in Kenya $51 \%$ of the respondents ate meat from animals which died from sickness (Mutua et al., 2017). This is probably because of the believe that meat from dead or sick animals can be eaten following treatment with Warbugia ugandensis, Acacia tortilis, Acacia nubica, and Myrisine africana leaves and upon boiling with herbs from these tree species as it was the case in Baringo County in Kenya (Mutua et al., 2017). In yet another study carried out in Gambia, Senegal, Guinea, and Guinea Bissau by Unger and Munstermann (2004), it was reported that a majority of participants consume meat from animals infected with brucellosis or tuberculosis after proper cooking or application of traditional treatment. The sale of dead or terminally sick animals to the public for consumption is a hazardous practice which has to be discouraged seriously by the authorities in order to check the infection of innocent consumers.

\section{Impact of Reproductive failures on cattle production}

In this study it was observed that reproductive failures have a great impact on cattle production as many unplanned culls and sales took place in the herds before the cattle market day thus reducing the herd size. The income generated from culls is usually very low since culls on-farm are usually cheaper than sales in the market. Although some farmers reported that they could treat these cases of reproductive failures traditionally there has been no effective control or treatment of infertility or abortions in the farms. Animal diseases and veterinary public-health problems constitute a major constraint to livestock production and safe consumption of animal products worldwide (FAO, 2002). The impact of disease on revenue was quite huge as seen in Figure 2. It can be seen that animals can be sold for a higher monetary value when they are healthy than when they are sick irrespective of their age. It was observed that weight loss due to disease and infertility were good enough reasons for a cow to be culled and sold and an emaciated animal would cost almost half the price of a similar animal of good health condition. Most of these animals were reported to come down with these infections when they came back from transhumance. However the farmers attributed their loss of weight to long treks and lack of pasture and water in the dry season during transhumance but according to Ndambi et al., 2008 many diseases and parasites are spread during the transhumance period, when these animals mingle with other herds from other locations as they graze together along fertile valleys. The impact of endemic diseases are mainly felt at farm level, but broader economic impacts occur with epidemic diseases that can result in the restriction of trade in livestock and livestock products. The occurrence of such diseases affects both the poor and rich livestock producers and relegates them from higher price livestock markets thus restricting their capacity for value-added trade (FAO, 2002). Increase in production can be achieved by a combination of expansion in animal numbers and increased productivity which include shorter production cycles and higher carcass weight and milk yields (Alexandratos and Bruinsma, 2012).

\section{Awareness of zoonoses as threat to public health}

Zoonotic infections are diseases which can be transmitted from animals to man. Some of the respondents were not aware that they could be contaminated by drinking unpasteurized milk or by poor handling of animal wastes, discharges and fetuses of aborted animals. It was observed that their interaction with the animals is limitless. Table 8 shows that out of the 209 people who responded to this question, $112(53.6 \%)$ of them were not aware of the transmission of zoonotic infections from animals to man. However, in Mezam Division there was a high level of awareness among the respondents interviewed $(39 \%, N=97, n=38)$. This could be due to the fact that most of the grazers in Mezam live around the Peri-urban areas and so are more exposed to 
knowledge through their frequent interactions with veterinary officers and researchers as their farms are easily accessible. On the contrary the lack of knowledge on zoonoses in some areas like in Donga Mantung Division was of great concern given that this is the area of highest cattle production in the Region. It was seen that most of the grazers live around their animals and milking of the animals which is an activity of the women and children is done in the mornings before the animals go to the field for grazing. Unger and Munstermann (2004), also reported a similar observation in rural areas and also in peri-urban livestock production centres, where there is a close relationship between the people and their animals, living under very poor hygienic conditions.

Table 8: Level of awareness of transmission of zoonotic diseases in the North West Region

\begin{tabular}{|l|l|l|l|}
\hline \multirow{2}{*}{ Division } & \multicolumn{3}{|l|}{ Awareness of the transmission } \\
\cline { 2 - 4 } & Yes (\%) & No (\%) & Total (\%) \\
\hline Mezam & $38(39)$ & $2(2)$ & $40(19)$ \\
\hline Momo & $11(11)$ & $25(22)$ & $36(17)$ \\
\hline Boyo & $22(23)$ & $5(5)$ & $27(13)$ \\
\hline Bui & $23(24)$ & $46(41)$ & $69(33)$ \\
\hline $\begin{array}{l}\text { Donga } \\
\text { Mantung }\end{array}$ & $3(3)$ & $34(30)$ & $37(18)$ \\
\hline Total & $\mathbf{9 7 ( 1 0 0 )}$ & $\mathbf{1 1 2 ( 1 0 0 )}$ & $\mathbf{2 0 9 ( 1 0 0 \% )}$ \\
\hline
\end{tabular}

$\chi^{2}=81.5, d f=4, p \leq 0.001$

Livestock products have a great impact on improving child nutrition among poor people, particularly in pastoralist communities, where $75 \%$ or more, of child nutrition is based on milk and livestock products. A study to assess the impact of zoonotic infections in selected regions of The Gambia, Senegal, Guinea, and Guinea Bissau indicated that cattle with hygroma, which is a typical symptom for brucellosis, are often not considered to be sick and milk is consumed without heat treatment (Unger and Munstermann, 2004). These results were however contrasting to those obtained from the study in Baringo County where majority of the survey respondents $(91.5 \%)$, reported that they always boiled their milk before consumption and $(62.4 \%)$ never consumed milk from sick livestock (Mutua et al. 2017). Aborted fetuses were disposed of, with unprotected hands and sometimes the herdsmen help some cows having difficulties during calving, without wearing gloves. Most of these grazers and herdsmen who expose themselves to these risks were ignorant of the transmission of such diseases from animals to man. It was however observed in this study that among the three categories of respondents [crop farmers (30), cattle grazers (150) and herdsmen (33)], the herdsmen $(90.9 \%) \mathrm{n}=30)$ had a higher level of awareness of zoonotic transmission than the cattle grazers and crop farmers (Table 9). The level of awareness was statistically very significant at $\chi^{2}=49.3, d f=2, P \leq$ 0.001 .
Table 9: Level of awareness of transmission of zoonotic diseases among cattle farmers

\begin{tabular}{|l|l|l|l|}
\hline $\begin{array}{l}\text { Category of } \\
\text { Respondent } \\
\mathrm{s}\end{array}$ & $\begin{array}{l}\text { No or of } \\
\text { Respondent } \\
\mathrm{s}\end{array}$ & $\begin{array}{l}\text { No aware } \\
\text { of disease } \\
\text { transmissio } \\
\mathrm{n}\end{array}$ & $\begin{array}{l}\text { Percentag } \\
\text { e } \\
\text { awarenes } \\
\mathrm{s}(\%)\end{array}$ \\
\hline $\begin{array}{l}\text { Crop } \\
\text { Farmers }\end{array}$ & 29 & 21 & 72.4 \\
\hline Grazers & 145 & 44 & 30.3 \\
\hline Herdsmen & 33 & 30 & 90.9 \\
\hline Total & $\mathbf{2 0 7}$ & $\mathbf{9 5}$ & $\mathbf{4 5 . 9}$ \\
\hline
\end{tabular}

$\chi^{2}=49.3, d f=2, p \leq 0.001$

Livestock diseases are controlled only to a limited extent because drugs are not readily available nor easily affordable for the rural and urban poor farmers and most of the grazers or herdsmen in this study, carried out the treatment themselves. A lot of money may be spent in controlling animal diseases, although the services received may not be effective due to lack of adequate knowledge. This is particularly true for smallholder farmers, who often lack information and have limited access to diagnostic data to make disease-control and treatment decisions.

Food security problems also arise when people lack knowledge about nutrition, food handling and preparation, lack access to clean water and sanitation or when their food supplies change and they have to deal with unfamiliar foodstuffs (FAO, 2011). Most of the cattle grazers and crop farmers use their manure from the sleeping paddocks for farming. Untreated manure is also a source of contamination from cattle suffering from fascioliasis.

\section{CONCLUSION / RECOMMENDATION}

This study which was aimed at assessing grazers' perception of reproductive failures and their effect on cattle production shows that reproductive failures have a great impact on cattle production in the North West Region and consequently on cattle production in Cameroon given that the North West Region is the second largest cattle production region in the country. The lack of knowledge by some of the people on the transmission of some infections from animals to humans is a public health concern and more sensitization should be carried out among the grazers. Consumption of raw milk by some members of the community and sale of dead animals for consumption should be discouraged. Due to the public health importance of zoonotic infections, it is recommended that blood samples be collected from the grazers and the members of their households involved in cattle rearing and tested for the prevalence of Brucellosis, RVF and fascioliasis (common zoonoses) in humans since most of seroprevalence studies carried out in the North West Region so far have been on animals. 
Table 2: Demographic information of respondents in the study

\begin{tabular}{|c|c|c|c|c|c|c|c|c|c|}
\hline \multirow{2}{*}{$\begin{array}{c}\text { Age } \\
\text { (Years) }\end{array}$} & \multicolumn{2}{|c|}{ Gender } & \multirow{2}{*}{$\begin{array}{c}\text { Total number } \\
\text { of } \\
\text { respondents }\end{array}$} & \multirow{2}{*}{$\begin{array}{c}\text { Percentage } \\
(\%)\end{array}$} & \multirow[t]{2}{*}{ Level of education } & \multicolumn{2}{|c|}{ Gender } & \multirow[t]{2}{*}{ Total number } & \multirow{2}{*}{$\begin{array}{c}\text { Percentage } \\
(\%)\end{array}$} \\
\hline & Female & Male & & & & Female & Male & & \\
\hline $18-30$ & 3 & 29 & 32 & 14.8 & Primary school graduate & 12 & 32 & 44 & 20.8 \\
\hline $31-50$ & 13 & 91 & 104 & 48.1 & Secondary school graduate & 1 & 9 & 10 & 4.7 \\
\hline $51-70$ & 6 & 52 & 58 & 26.9 & High school graduate & 0 & 2 & 2 & 0.9 \\
\hline \multirow[t]{3}{*}{$71^{+}$} & 4 & 18 & 22 & 10.2 & University graduate & 0 & 2 & 2 & 0.9 \\
\hline & & & & & None & 12 & 122 & 134 & 63.2 \\
\hline & & & & & koranic School & 0 & 20 & 20 & 9.4 \\
\hline Total & 26 & 190 & 216 & 100.0 & Total & 25 & 187 & 212 & 100 \\
\hline
\end{tabular}

\begin{tabular}{|c|c|c|c|c|c|c|}
\hline \multirow[t]{2}{*}{ Type of reproductive failure } & \multicolumn{5}{|c|}{ Division } & \multirow{2}{*}{$\begin{array}{l}\text { Total } \\
\mathrm{N}(\%)\end{array}$} \\
\hline & $\begin{array}{l}\text { Mezam } \\
\mathrm{N}(\%)\end{array}$ & $\begin{array}{l}\text { Momo } \\
\mathrm{N}(\%)\end{array}$ & $\begin{array}{l}\text { Boyo } \\
\mathrm{N}(\%)\end{array}$ & $\begin{array}{l}\text { Bui } \\
\mathrm{N}(\%)\end{array}$ & $\begin{array}{c}\text { Donga Mantung } \\
\mathrm{N}(\%)\end{array}$ & \\
\hline Embryonic death & $31(77.5)$ & 4 (13.3) & $5(18.5)$ & $9(12.9)$ & $2(5.4)$ & $51(25.0)$ \\
\hline Abortion & $8(20.0)$ & $10(33.3)$ & $3(11.1)$ & $21(30.0)$ & $3(8.1)$ & $45(22.1)$ \\
\hline Infertility & $1(2.5)$ & $2(6.7)$ & $1(3.7)$ & $9(12.9)$ & $2(5.4)$ & $15(7.4)$ \\
\hline Reduced milk quantity & $0(0)$ & $0(0)$ & $0(0)$ & $5(7.1)$ & $0(0)$ & $5(2.5)$ \\
\hline Embryonic death and abortion & $0(0)$ & $4(13.3)$ & $0(0)$ & $0(0)$ & $0(0)$ & $4(2.0)$ \\
\hline Abortion and infertility & $0(0)$ & $0(0)$ & $0(0)$ & $0(0)$ & $13(35.1)$ & $13(6.4)$ \\
\hline Embryonic death, abortion and infertility & $0(0)$ & $0(0)$ & $0(0)$ & $0(0)$ & $3(8.1)$ & $3(1.5)$ \\
\hline Embryonic death, abortion, infertility, reduced milk quantity & $0(0)$ & $0(0)$ & $15(55.6)$ & $18(25.7)$ & $2(5.4)$ & $35(17.2)$ \\
\hline Foot and mouth, blood urine, cough, any other disease & $0(0)$ & $10(33.3)$ & $3(11.1)$ & $8(11.4)$ & $12(32.4)$ & $33(16.2)$ \\
\hline Total & $40(19.6)$ & $30(14.7)$ & $27(13.2)$ & $70(34.3)$ & $37(18.1)$ & $204(100)$ \\
\hline
\end{tabular}

Table 3: Types of reproductive failures identified by different respondents in their farms

$$
\chi^{2}=2.3, d f=32, p \leq 0.001
$$

\begin{tabular}{|c|c|c|c|c|c|c|}
\hline \multirow{2}{*}{$\begin{array}{l}\text { Period when } \\
\text { reproductive failures } \\
\text { are common }\end{array}$} & \multicolumn{6}{|c|}{ Division } \\
\hline & $\begin{array}{l}\text { Mezam } \\
\text { N (\%) }\end{array}$ & $\begin{array}{l}\text { Momo } \\
\text { N (\%) }\end{array}$ & $\begin{array}{l}\text { Boyo } \\
\text { N (\%) }\end{array}$ & $\begin{array}{l}\text { Bui } \\
\text { N (\%) }\end{array}$ & $\begin{array}{l}\text { Donga Mantung } \\
\text { N (\%) }\end{array}$ & $\begin{array}{l}\text { Total } \\
\text { N (\%) }\end{array}$ \\
\hline Year round & $11(27.5)$ & $23(71.9)$ & 25 (83.3) & $54(85.7)$ & $24(66.7)$ & $137(68.2)$ \\
\hline Dry season & $29(72.5)$ & $1(3.1)$ & $3(10.0)$ & $5(7.9)$ & $9(25.0)$ & $47(23.4)$ \\
\hline Rainy season & $0(0)$ & $8(25)$ & $2(6.7)$ & $4(6.4)$ & $3(8.3)$ & $17(8.4)$ \\
\hline Total & $40(100)$ & $32(100)$ & $30(100)$ & $63(100)$ & $36(100)$ & $201(100)$ \\
\hline
\end{tabular}

$$
\chi^{2}=90.8, d f=8, p=0.001
$$


Table 5: Grazing systems in the North West Region

\begin{tabular}{|l|l|l|l|l|l|l|}
\hline \multirow{2}{*}{ Grazing system } & Division & \multicolumn{3}{l|}{} \\
\cline { 2 - 7 } & Mezam & $\begin{array}{l}\text { Momo } \\
\mathbf{N}(\%)\end{array}$ & $\begin{array}{l}\text { Boyo } \\
\text { N (\%) }\end{array}$ & $\begin{array}{l}\text { Bui } \\
\mathbf{N}(\%)\end{array}$ & $\begin{array}{l}\text { Donga Mantung } \\
\mathbf{N}(\%)\end{array}$ & $\begin{array}{l}\text { Total } \\
\mathbf{N}(\%)\end{array}$ \\
\hline Free pastures (Extensive) & $39(97.5)$ & $38(97.4)$ & $26(96.3)$ & $72(100)$ & $37(100)$ & $\mathbf{2 1 2 ( 9 8 . 6 )}$ \\
\hline Exclusively intensive & $1(2.5)$ & $0(0)$ & $1(3.7)$ & $0(0)$ & $0(0)$ & $\mathbf{2 ( 0 . 9 )}$ \\
\hline Semi intensive & $0(0)$ & $1(2.6)$ & $0(0.00)$ & $0(0)$ & $0(0)$ & $\mathbf{1 ( 0 . 5 )}$ \\
\hline Total & $\mathbf{4 0 ( 1 0 0 )}$ & $\mathbf{3 9 ( 1 0 0 )}$ & $\mathbf{2 7 ( 1 0 0 )}$ & $\mathbf{7 2 ( 1 0 0 )}$ & $\mathbf{3 7 ( 1 0 0 )}$ & $\mathbf{2 1 5}(\mathbf{1 0 0})$ \\
\hline
\end{tabular}

Table 7: Outcome of dead animals

\begin{tabular}{|c|c|c|c|c|c|}
\hline \multirow[t]{2}{*}{ Division } & \multicolumn{5}{|c|}{ Respondents that consumed the dead animal } \\
\hline & $\begin{array}{l}\text { Yes } \\
\text { N (\%) }\end{array}$ & $\begin{array}{l}\text { No } \\
\text { N (\%) }\end{array}$ & $\begin{array}{l}\text { buried } \\
\mathrm{N}(\%)\end{array}$ & $\begin{array}{l}\text { sold } \\
\mathrm{N}(\%)\end{array}$ & $\begin{array}{l}\text { Total } \\
\text { N (\%) }\end{array}$ \\
\hline Mezam & $0(0)$ & $13(13.5)$ & $0(0)$ & $3(6.3)$ & $16(10.4)$ \\
\hline Momo & $5(83.3)$ & $16(16.7)$ & $2(50.0)$ & $10(20.8)$ & $33(21.4)$ \\
\hline Boyo & $0(0)$ & $4(4.2)$ & $1(25.0)$ & $20(41.7)$ & $25(16.2)$ \\
\hline Bui & $0(0)$ & $35(36.5)$ & $0(0)$ & $15(31.2)$ & $50(32.5)$ \\
\hline $\begin{array}{l}\text { Donga } \\
\text { Mantung }\end{array}$ & $1(16.7)$ & $28(29.2)$ & $1(25.0)$ & $0(0)$ & $30(19.5)$ \\
\hline Total & $6(3.9)$ & 96(62.3) & $4(2.6)$ & 48(31.2) & $154(100)$ \\
\hline
\end{tabular}

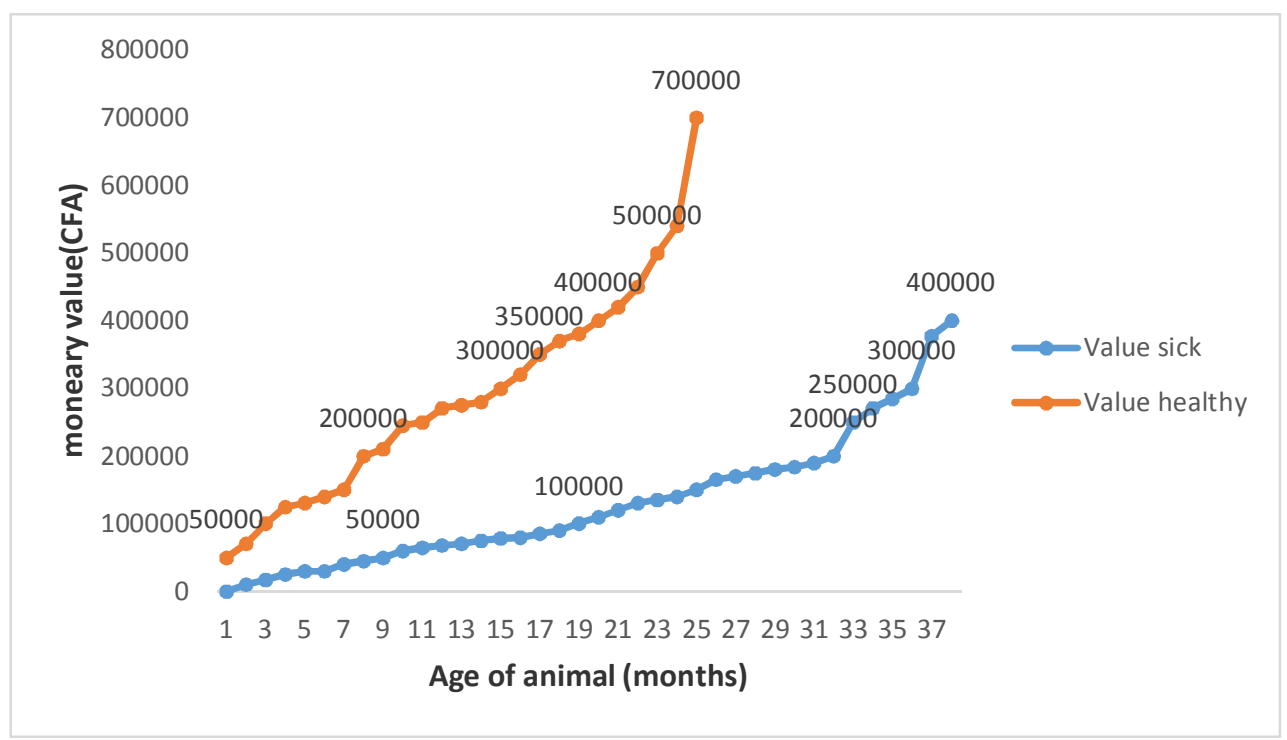

Fig 2: Impact of Reproductive Diseases on farmers' income

\section{CONFLICT OF INTEREST}

The authors declare that there is no conflict of interest

\section{ACKNOWLEDGEMENT}

We sincerely acknowledge the assistance of $\mathrm{Dr}$ Ndaleh W. in carrying out part of the statistical analysis of this work

\section{REFERENCES}

Alexandratos, N. and J. Bruinsma. (2012). World agriculture towards 2030/2050: the 2012 revision. ESA Working paper No. 12-03. Rome, FAO.

Bayemi P. H., Bryant M. J., Perera B M A O, Mbanya N J, Cavestany D and Webb E C (2005). Milk production in Cameroon: A Review. Livestock Research for Rural Development 17 (6). www.cipav.org.co//rrd//rrd17/6/cont1706

Bayemi, P.H., Leinyuy I., Nsongka V.M., Webb, E.C., Ebangi A.L., (2010). Viability of cattle sperm under 
different storage conditions in Cameroon. Tropical Animal Health and Production. 42:1779-1783

Bayemi, P. H., Mah, G. D., Ndamukong, K., Nsongka, V.M., Leinyuy, I., Unger, H., Ndoumbe, N. M., Webb, E.C., Achukwi, M. D. Hakoueu, F. Luogbou, N.D., (2015). Bovine Brucellosis in Cattle production Systems in the Western Highlands of Cameroon, International Journal of Animal Biology 1 (2): $38-44$

Beddington, J. (2010). Food security: contributions from science to a new and greener revolution. Philosophical Transactions of the Royal Society B, 365: 61-71

Bellows D.S., S. L. Ott, S.L., and Bellows, R.A. (2002). Cost of Reproductive Diseases and Conditions in Cattle. The Professional Animal Scientist 18:2632.

FAO (2002). Improved animal health for poverty reduction and sustainable livelihood. FAO Animal and health paper, No. 153. Rome, Italy

FAO Statistics Division (2006). Food deprivation trends: midterm review of progress towards the World Food Summit target. Working Paper Series WP007e, FAO, Rome, Italy.

FAO (2008). Briefing paper: hunger on the rise. Rome, Italy

FAO. (2011). World Livestock 2011 - Livestock in food security. Rome, Italy.

Godfray, H.C.J., Beddington, J.R., Crute, I.R., Haddad, L., Lawrence, D., Muir, J.F., Pretty, J., Robinson, S., Thomas, S.M., Toulmin, C., (2010). Food Security: The Challenge of Feeding 9 Billion People. Science 327:812-818.

Haileselassie, M. Kalayou, S. M. Kyule, M. Asfaha, M. and Belihu, K. (2011). Effect of Brucella Infection on Reproduction Conditions of Female Breeding Cattle and Its Public Health Significance in Western Tigray, Northern Ethiopia. Veterinary Medicine International

ILRI (2012). 13 zoonoses responsible for 2.4 B cases of human illness per year. www.newsmedical.net/news. Date Accessed 16/07/2012

Kong A.T., Nsongka M.V., Itoe S.M., Hako A.T., Leinyuy I. (2016). Seroprevalence of Brucella abortus in the Bamenda Municipal Abattoir of the Western Highlands, of Cameroon. Greener Journal of Agricultural Sciences, 6(8): 245- 251

Lamb G. C., Dahlen C., Mercadante V.R.G, and Bischoff K. (2014). What Is the Impact of Infertility in Beef Cattle?

Manu I.N., Andu W.N., Tarla D.N., Agharih W.N., (2014). Socio-economic effect of cattle theft on the pastoralists of the North West Region of Cameroon. Scholarly Journal of Agricultural Science 4 (6): 299-305
Marcotty T., Matthys F., Godfroid J., Rigouts L., Ameni G., Gey Van Pittius N., Kazwala R, Muma J., Van Helden J., Walravens K., De Klerk L.M., Geoghegan C., Mbotha D., Otte M., Amenu K., Abu Samra N., Botha C., Ekron M., Jenkins A., Jori F., Kriek N., Mccrindle C., Michel A., Morar D., Roger F., Thys E. And Van Den Bossche P. (2009). Zoonotic tuberculosis and brucellosis in Africa: neglected zoonoses or minor public-health issues? The outcomes of a multi-disciplinary workshop. Annals of Tropical Medicine \& Parasitology 103 (5): 401-411

Mutua E. N., Bukachi S. A., Bett B. K., Estambale B. A., Nyamongo I. K. (2017) "We do not bury dead livestock like human beings": Community behaviors and risk of Rift Valley Fever virus infection in Baringo County, Kenya. PLoS Neglected Tropical Disease 11(5): e0005582. https://doi.org/10.1371/journal.pntd.0005582

Nchinda, V.P., M.A. Che, P. ljang, A.A. Shidiki, and N. Chi. 2014. Baseline survey report: "In Search of Common Grounds for farmer-grazer conflicts in the North West region of Cameroon". MBOSCUDACameroon MBOSCUDA-Cameroon

Ndambi, O. A., Tchouamo, I., Bayemi, P. H. and Hemme, T. (2008). Milk production amongst Fulani grazers in the Western Highlands of Cameroon: Constraints and development peerspectives. Livestock Research for Rural Development 20(1) http/www.Irrd. org//rrd20/1/cont2001httm. Date Accessed 25/11/2011

Ngalim, A.N., (2015). Cattle Rearing Systems in the North West Region of Cameroon: Historical Trends on Changing Techniques and Strategies. Journal of Educational Policy and Entrepreneurial Research. 2 (5): 175-189

Parente S. and van de Weerd H., (2012). Food Security and Farm Animal Welfare. ciwf.org/foodsecurity or wspainternational.org/farming

Pingpoh, D.P., Mbanya Justin, Ntam Fidelis, Malaa Dorothy K, (2007). Some risk management practices among the beef cattle farmers of the North West Province of Cameroon: effect on technology dissemination

Sprott, L.R. and Field R.W. (1998). Reproductive diseases in cattle.

Unger Fred and Münstermann Susanne, (2004). Assessment of the impact of zoonotic infections (bovine tuberculosis and brucellosis) in selected regions of The Gambia, Senegal, Guinea, and Guinea Bissau - A Scoping study

World Development Report 2008: Agriculture for Development. Washington, DC. World Bank. 